\title{
Pengembangan Video Pembelajaran Matematika Berbantuan Media Sosial Instagram sebagai Alternatif Pembelajaran
}

\author{
Reza Rizki Ali Akbar ${ }^{1}$, Komarudin ${ }^{1}$ \\ 1Universitas Islam Negeri Raden Intan Lampung, Jalan Endro Suratmin, Sukarame, Bandar \\ Lampung 35133, Indonesia \\ ${ }^{*}$ Corresponding Author. E-mail: rezarizky456@gmail.com
}

Received : 06-03-2018; Revised : 13-05-2018; Accepted : 31-05-2018

\begin{abstract}
Abstrak
Penelitian ini bertujuan untuk mengembangkan dan menguji kelayakan video pembelajaran matematika berbantuan media sosial instagram sebagai alternatif pembelajaran berdasarkan kelayakan dari penilaian Ahli media dan Ahli materi. Metode penelitian ini 7 tahap dari 10 tahap model Borg and Gall yang telah dimodifikasi oleh Sugiyono yang meliputi Potensi dan Masalah, Mengumpulkan Data, Desain Produk, Validasi Desain, Revisi Desain, Uji Coba Produk serta Revisi Produk. Penelitian ini menghasilkan sebuah media video pembelajaran matematika berbantuan media social Instagram yang telah dinyatakan valid dan layak digunakan sebagai media pembelajaran matematika oleh 3 ahli materi yang ememperoleh skor rata-rata 88,8 (Sangat layak) dan 3 ahli media dengan perolehan skor rata-rata 93,55 (Sangat Layak) dengan masing-masing skor maksimal kelayakan adalah 100. Sehingga dapat disimpulkan bahwa media video pembelajaran matematika berbantuan instagram sebagai alternative pembelajaran valid dan layak digunakan sebagai media pembelajaran matematika.
\end{abstract}

Kata Kunci : Instagram; Media Sosial; Video Pembelajaran Matematika.

\begin{abstract}
This study aims to develop and test the feasibility of instructional videos of assisted social media Instagram as an alternative learning based on the feasibility of the assessment of media experts and materials experts. This research method is 7 stages from 10 stages of Borg and Gall model which have been modified by Sugiyono covering Potency and Problem, Collecting Data, Product Design, Design Validation, Design Revision, Product Trial and Product Revision. This research produces a medium of instructional video of math-aided social media of Instagram which has been declared valid and proper to be used as media of mathematics learning by 3 material experts get average score 88,8 (Very worthy) and 3 media expert with average score 93,55 (Very Eligible) with each maximum score of eligibility is 100. So it can be concluded that the instructional media of instructional-assisted mathematics Instagram as a valid learning alternative and suitable for use as a medium of learning mathematics.
\end{abstract}

Keywords: Instagram; Social media; Mathematics Learning Videos.

\section{PENDAHULUAN}

Pada era kemajuan ilmu engetahuan tehnologi, tentunya pendidikan harus mengikuti perkembangan zaman yang ada. Karena pendidikan merupakan sarana untuk menuju kepada pertumbuhan dan perkembangan bangsa. Pendidikan juga merupakan investasi sumber daya manusia jangka panjang yang mempunyai nilai strategis bagi kelangsungan peradaban manusia di dunia (Yuliasari, 2017). Maka dari itu pendidikan menjadi salah satu modal penting untuk memajukan sebuah bangsa karena kesejahteraan dan kemajuan sebuah bangsa dapat dilihat dari tingkat pendidikannya. Pendidikan memegang peranan penting dalam menciptakan individu berkualitas (Widyawati, 2016). Maka dari itu sudah seharusnya sudah ada inivasi-inovasi dalam dunia 
pendidikan sebagai jembatan untuk mengembangkan kreatifitas siswa. Salah satu pendidikan yang dapat mengembangkan kemampuan serta kreatifitas adalah pendidikan matematika yang berarti didalamnya terdapat pelajaran matematika (Anggoro, 2016; Cahyono, 2017).

Pelajaran matematika sebagai salah satu ilmu yang tidak kalah pentingnya dalam upaya meningkatkan mutu pendidikan dan kehidupan bangsa. Paradigma dalam pembelajaran matematika membawa dampak pada penekanan pada perubahan siswa dalam proses pembelajaran. Perubahan tersebut mengubah fokus seluruh paradigma dalam suatu pendidikan matematika di seluruh dunia (Rahmadi, 2015). Pelajaran matematika salah satu mata pelajaran yang memiliki manfaat besar dalam kehidupan (Sari, 2016). Salah satu tujuan pembelajaran matematika adalah peserta didik dapat menerapkan matematika secara tepat dalam kehidupan sehari-hari serta dalam berbagai ilmu pengetahuan, guna mempersiapkan dan meningkatkan kualitas sumber daya manusia(Putri, Parmiti, \& Dr. I Komang Sudarma, 2017). Maka dari itu sudah sepatutnya pembelajaran matematika sudah terwudjud dengan baik dan sesuai harapan para pendidik. Namun untuk mewujudkan pembelajaran Matematika yang baik, banyak sekali permasalahan yang harus diselesaikan (Hamdi \& Abadi, 2014). Seperti permasalahan dalam proses kegiatan pembelajaran yang selalu berkutat dengan metode konvesional dan disuguhi dengan buku ajar. Perlunya memiliki kelengkapan pembelajaran yang memadai agar kegiatan belajar mengajar di kelas berjalan sesuai dengan kompetensi dasar yang diharapkan menjadi hal penting dalam proses pembelajaran matematika (Supriadi, 2015). Hal ini diperkuat juga dengan penggunaan metode yang kurang bervariasi dan minimnya penggunaan media pembelajaran sehingga diduga bisa menyebabkan proses pembelajaran matematika terkesan monoton dan kurang kreatif (Masykur, Nofrizal, \& Syazali, 2017).

Melihat maju tehnologi yang ada penulis menganggap bahwa metode konvensional dalam pembeljaran matematika sudah tidak relevan lagi. Pembelajaran yang terkesan konvensional tersebut selain kurang maksimal dalam memenuhi kebutuhan siswa juga terasa membosankan (Irwandani, 2016). Oleh karena itu, diperlukan media pembelajaran yang bersifat mandiri yang dapat membuat pembelajaran lebih menarik. Sehingga penulis terarik melakukan sebuah penelitian dengan menggunakan video pembelajaran berbantuan media sosial instagram sebagai media pembelajaran matematika guna mengatasi kejenuhan dan kebosanan siswa. Menurut penelitian sebelumnya bahwa media video pembelajaran dapat meningkatkan komunikasi pembelajaran kepada siswa, selain itu media video pembelajaran juga dapat meningkatkan daya ingat siswa. Namun media ini masih dilakukan dengan cara offline, sehingga belum terlihat memanfaatkan media sosial yang telah ada. Penelitian dengan menggunakan Media video yang telah dikembangkan secara online yaitu menggunakan media social instagram dengan hasil bahwa siswa memberikan respon yang positif dalam proses belajar, siswa juga dapat menggunakan dimana saja berada tidak mesti harus di sekolah. Namun media ini hanya menggunankan komik pembelajaran bukan video pembelajaran. Tetapi tetap saja dapat disimpulkan bahwa jika pembelajaran menggunakan video pembelajaran memberikan kelebihan tersendiri (Irwandani \& Juariyah, 2016; Nugraha, 2015; Purwanti, 2015; Putri et al., 2017).

Berlandasakan peneliitian terdahulu yang telah relevan, penulis 
melakukan keterbaharuan dalam penelitian. Penelitian ini dilakukan dengan mengombinasikan media social instagram dengan video pembelajaran dalam pembelajaran matematika. Tujuan agar siswa memanfaatkan media sosial yang telah tersedia lebih positif dalam pembelajaran.

\section{METODE PENELITIAN}

Jenis penelitian ini adalah penelitian penelitian dan pengembangan (research and Development). Prosedur yang digunakan adalah 7 tahap dari 10 tahap metode dari Borg and Gall dimodifikasi oleh Sugiyono yaitu Potensi dan Masalah, Mengumpulkan Data, Desain Produk, Validasi Desain, Revisi Desain, Uji Coba Produk, Revisi produk (Sugiyono, 2012).

Tabel 1. Skor Penilaian Validasi Ahli

\begin{tabular}{cl}
\hline Skor Presentase & Kriteria Kelayakan \\
$0 \leq P \leq 20$ & Sangat Kurang \\
$20 \leq P \leq 40$ & Kurang \\
$40 \leq P \leq 60$ & Cukup Baik \\
$60 \leq P \leq 80$ & Baik \\
$80 \leq P \leq 100$ & Sangat Baik \\
\hline
\end{tabular}

Selanjutnya dilakukan perhitungan tiap butir pertanyaan menggunakan rumus sebagai berikut:

$$
\mathrm{P}=\frac{\sum x}{\text { skor maksimal }} \times 100 \%
$$

Keterangan :

$$
\begin{aligned}
& \mathrm{P} \quad=\text { Persentase kelayakan } \\
& \sum x=\text { jumlah skor } \\
& \text { Langkah terakhir adalah }
\end{aligned}
$$

Tabel 2. Kriteria Validasi

\begin{tabular}{cc}
\hline Skor & Pilihan Jawaban Kelayakan \\
5 & Sangat Baik \\
4 & Baik \\
3 & Cukup aik \\
2 & Kurang Baik \\
1 & Sangat Kurang Baik \\
\hline
\end{tabular}

\section{HASIL PENELITIAN DAN PEMBAHASAN}

Hasil utama penelitian dan pengembangan ini adalah sebuah media video pembelajaran matematika berbantuan media social instagram sebagai alternative pembelajaran. Penelitian dan pengembangan ini dilakukan dengan menggunakan prosedur pengembangan dari 7 tahap dari 10 tahap Borg and Gall yang dimodifikasi oleh Sugiyono.

Tahap pertama masalah adalah minimnya penggunaan media pembelajaran dalam pembelajaran matematika. Potensi yang ada banyaknya peserta didik yang telah memiliki akun media sosial instagram yang bisa dimanfaatkan sebagai bahan ajar sebagai alat bantu dalam pembelajaran matematika. Sehingga penulis mngembangankan media video pembelajaran berbantuan media social Instagram sebagai bahan ajar yang alternative. Pada tahap kedua penulis mengumpulkan informasi terkait kebutuhan dalam penelitian ini. Pengumpulan informasi sangat penting untuk mengetahui kebutuhan peserta didik terhadap produk yang dikembangkan melalui pengembangan dan penelitian. Informasi yang dikumpulkan dalam penelitian ini yaitu (1) KI, KD, Indikator dan Silabus dari kurikulum 2013; (2) Materi Aritmetika Sosial; (3) Buku-buku yang digunakan dari kurikulum 2013; (4) Peserta didik menggunakan handphone berbasis Android; (5) Pengumpulan gambargambar yang sesuai dengan materi; (6) Aplikasi yang digunakan untuk membuat video adalah Sparkol VideoScribe; (7) Aplikasi untuk meng-upload video adalah Instagram dengan maksimal durasi 60 detik. Setelah potensi masalah dan informasi teridentifikasi selanjutnya penulis mulai melakukan desain produk. Ada beberapa hal yang dilakukan dalam tahap desain produk pengembangan video pembelajaran matematika 
berbantuan media sosial instagram sebagai alternatif pembelajaran. Langkahlangkah penyusunan desain produk video ini, diantaranya adalah menyesuaikan standar kompetensi dan kompetensi dasar berdasarkan kurikulum K13. materi aritmetika sosial, dengan menggunakan instagram video pembelajaran akan ditampilkan selama 60 detik. Setelah desain produk selesai, kemudian dilakukan penilaian oleh para ahli. Penilaian para ahli ini penting guna mencapai tujuan yang hendak dicapai penulis dalam penelitian dan pengembangan ini. Validasi video pembelajaran berbantuan media sosial instagram dilakukan oleh 6 ahli, yang terdiri dari 3 ahli materi, 3 ahli media. Penilaian validasi ahli materi dianalisis 3 aspek yaitu aspek kelayakan isi, aspek ketepatan cakupan dan aspek kebahasaan.

Hasil validasi oleh ahli materi pada produk yang disajikan dalam bentuk grafik Gambar 1.

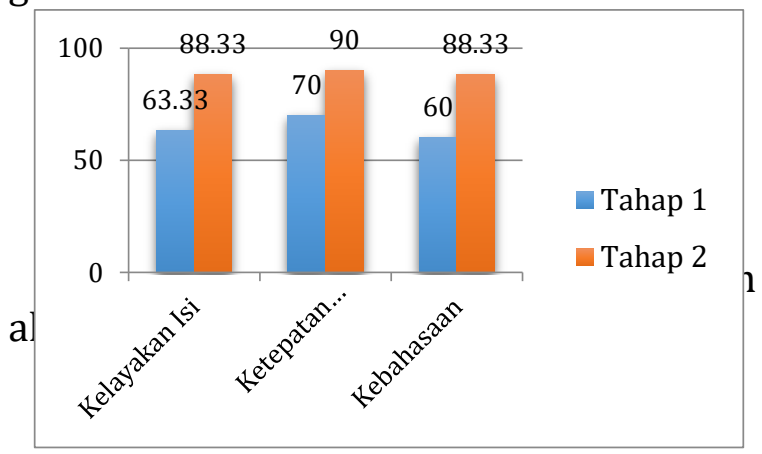

\section{Gambar 1. Hasil Validasi Ahli Materi}

Berdasarkan Gambar 1. terlihat bahwa hasil validasi berdasarkan ahli materi pada tahap satu dan tahap kedua terjadi peningkatan dari masing-masing aspek yang dinilai. Pada aspek kelayakan isi validasi tahap 1 dan tahap 2 jumlah peningkatan skor sebanyak 25, pada aspek ketepatan cakupan dengan jumlah peningkatan skor mencapai 20, pada aspek kebahasaan dengan jumlah peningkatan skor mencapai 28,33. Perolehan rata-rata skor hasil validasi ahli materi mencapai 88,8 dengan kriteria sangat layak.

Validasi selanjutnya yaitu validasi ahli media, hasil validasi oleh ahli media pada produk disajikan dalam bentuk grafik pada Gambar 2.

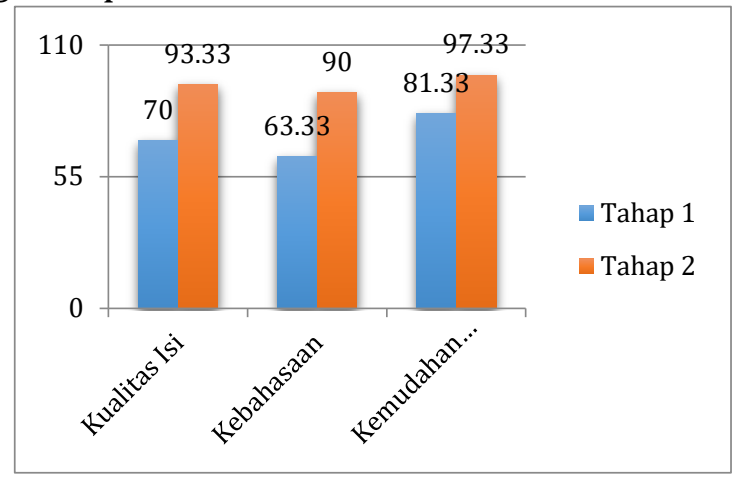

Gambar 2. Hasil Validasi Ahli Media

Berdasarkan Gambar 2. Dapat dilihat bahwa menunjukkan hasil validasi oleh ahli media dengan masing- masing peningkatan dari tahap 1 ke tahap 2 . Pada aspek kualitas isi skor meningkat dengan jumlah sebanyak 23,33, pada aspek kebahasaan skor meningkat dengan jumlah sebanyak 26,67. pada aspek kemudahan penggunaan skor meningkat dengan jumlah sebanyak 16 . Perolehan rata-rata skor dari validasi oleh ahli media mencapai skor 93,5 dengan kriteria sangat layak.

Berdasarkan validasi oleh ahli materi dan ahli media maka media video pembeljaran berbantuan instagram layak digunakan sebagai bahan ajar matematika. Kelayakan media pembelajaran tentunya tidak terlepas dari masukan dari saran dari para ahli. Pada tahap ini akan dipaparkan perbaikan desain media video pembelajaran berbantuan media social instagram. Hasil perbaikan desain dapat dilihat pada Gambar 4. 
Desimal, 1 (2), 2018 - 213

Reza Rizki Ali Akbar, Komarudin

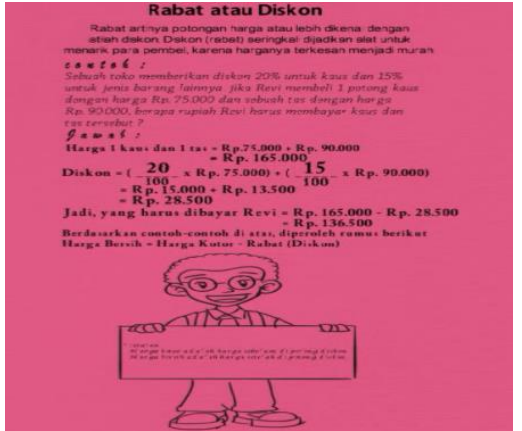

Gambar 3. Validasi Ahli materi Sebelum revisi

Berdasarkan validasi ahli materi memberikan saran tentang perbaikan pada contoh soal karena pada Gambar 3. masalah yang disajikan pada video belum ada gambar yang sesuai. Validator menyarankan untuk menambahkan gambar yang sesuai dengan soal, sehingga penulis mengadakan perbaikan desain penelitian. Perbaikan berdasarkan ahli materi dapat dilihat pada gambar 4 .

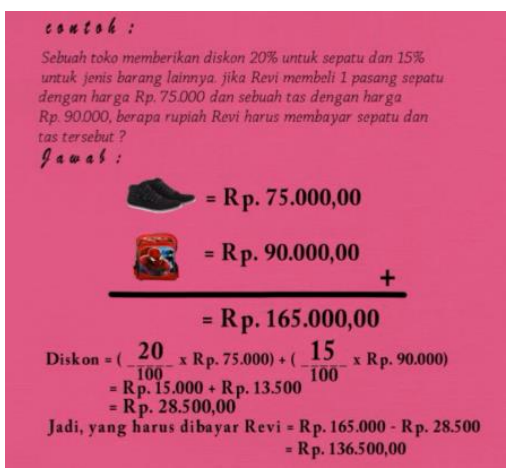

Gambar 4. Perbaikan Ahli materi Sesudah revisi

Perbaikan yang dilakukan adalah dengan menambahkan gambar tas dan sepatu yang sesuai dengan soal yang. Selain itu pengertian dari rabut dihapus sehingga tampilan terlihat tidak terlalu membingungkan.

Selain mendapatkan penilaian sangat layak dan oerbaikan dari ahli materi. Penilaian layak juga debrikan oleh ahli media berdasrkan beberapa kali revisi dengan ahli media dari berbagai aspek. Kelayakan media tentunya juga tidak terlepas dari saran dan masukan oleh ahli media. Gambar pada penilaian ahli media data dilihat pada Gambar 5.

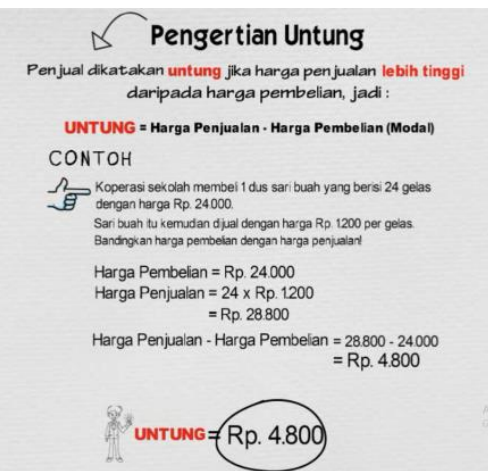

\section{Gambar 5. Validasi Ahli Media Sebelum revisi}

Perbaikan berdasarkan ahli media mendapatkan saran dan masukan bahwa tulisan pada produk awal pengembangan terlalu banyak, serta gambar belum mewakili isi dari materi, oleh karena itu dilakukan perbaikan agar animasi atau gambar lebih banyak dan sesuai dengan materi, sehingga dapat menarik perhatian peserta didik dalam belajar. Hasil dari perbaikan dapat dilihat pada gambar 6 .

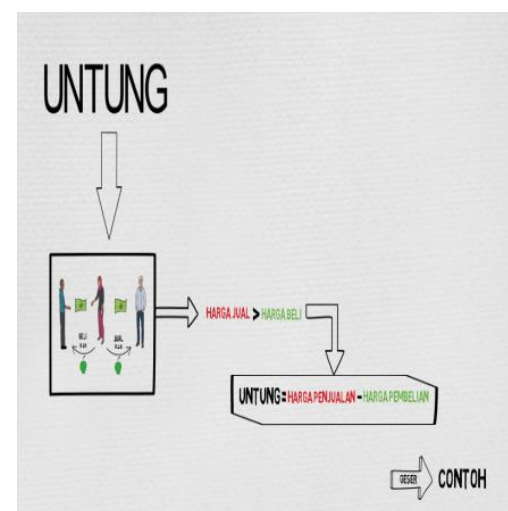

Gambar 4. Perbaikan Ahli Media Animasi
video

Perbaikan dilakukan adalah dengan mengubah text pada tampilan media mejadi sebuah animasi dengan system keuntungan. Setelah media sudah divalidasi dan diperbaiki maka media layak digunakan sebagai uji coba produk. Uji coba produk hanya untuk meyakinkan media video pembelajaran berdasarkan respon siswa dengan respon yang 
diberikan siswa sangat antusias dan sangat menarik dengan hadirnya media video pembelajaran berbatuan media social instagram dalam pembelajaran matematika. Karna media hanya melihat kelayakan dari hasil kevalidan oleh para ahli serta respon yang diberikan siswa sudah sangat menarik aka pada tahap ini tidadk dilakukannya perbaikan media lagi. Hasil penelitian ini sama dengan hasil penelitian oleh (Purwanti, 2015) bahwa media video pembelajaran yang dikembangakan layak sebagai media pembelajaran dengan perolehan skor dari para ahli materi dan desain yang dinyatakan $85 \%$ media layak digunakan sebagai media pembelajaran. Selain itu penelitian ini juga sama dengan hasil penelitian yang dilakukan oleh (Farista \& Ali, 2018; Putri et al., 2017) yang menyatakan bahwa media video pemeblajaran dinyatakan layak dan mendapatkan repon yang sangat menarik oleh siswa

\section{SIMPULAN DAN SARAN}

Berdasarkan hasil penelitian yang telah dipaparkan pada pembahasan sebelumnya maka dapat ditarik kesimpulan bahwa penelitian ini menghasilkan sebuah media video pembelajaran berbantuan media sosial instagram dalam pembelajaran matematika. Hasil uji kelayakan dinilai oleh ara ahli yaitu ahli materi dengan peroleh skor 88,8 dan ahli media memperoleh skor rata-rata 93,5 dengan kriteria sanagat layak.

Berdasarkan kesimpulan yang telah ditarik penulis menyarankan bahwa video pembelajaran berbantuan media sosial instagram dapat dikembangkan dengan materi yang lebih luas. Kemudian video pembelajaran matematika berbantuan media sosial instagram masih banyak kekurangan dalam pembuatan atau pengembangannya sehingga pengembangan video selanjutnya dapat dikembangkan video pembelajaran matematika berbantuan media sosial instagram yang lebih baik, agar dapat membuat motivasi dan menambah minat peserta didik dalam mengikuti pelajaran matematika dengan aktif.

\section{DAFTAR PUSTAKA}

Anggoro, B. S. (2016). Meningkatkan Kemampuan Generalisasi Matematis Melalui Discovery Learning dan Model Pembelajaran Peer Led Guided Inquiry. Al-Jabar: Jurnal Pendidikan Matematika, 7(1), 11-20. https://doi.org/10.24042/ajpm.v7i1 .23

Cahyono, A. E. Y. (2017). Pengembangan perangkat pembelajaran dengan model PBL berorientasi pada kemampuan berpikir kreatif dan inisiatif siswa. Pythagoras: Jurnal Pendidikan Matematika, 12(1), 1-11.

Farista, R., \& Ali, I. (2018). Pengembangan Video Pembelajaran. Pengembangan Video Pembelajaran, 1-6.

Hamdi, S., \& Abadi, A. M. (2014). Pengaruh motivasi, self-efficacy dan latar belakang pendidikan terhadap prestasi matematika mahasiswa PGSD STKIP-H dan PGMI IAIH. Jurnal Riset Pendidikan Matematika, 1(1), 77-87.

Irwandani, I. (2016). Potensi Media Sosial dalam Mempopulerkan Konten Sains Islam. Tadris: Jurnal Keguruan Dan Ilmu Tarbiyah, 1(2), 173-177.

Irwandani, I., \& Juariyah, S. (2016). Pengembangan Media Pembelajaran Berupa Komik Fisika Berbantuan Sosial Media Instagram sebagai Alternatif Pembelajaran. Jurnal Ilmiah Pendidikan Fisika Al-Biruni, 5(1), https://doi.org/10.24042/jpifalbiru ni.v5i1.103

Nugraha, A. (2015). Fenomena Meme Di Media Sosial (Studi Etnografi Virtual Posting Meme Pada Pengguna Media Sosial Instagram). Jurnal Sosioteknologi, 14(3), 237-245. 
Purwanti, B. (2015). Pengembangan Media Video Pembelajaran Matematika dengan Model Assure. Jurnal Kebijakan Dan Pengembangan Pendidikan, 3(1).

Putri, N. M. L. K., Parmiti, D. D. P., \& Dr. I Komang Sudarma, S. P. (2017). Pengembangan Video Pembelajaran dengan Bahasa Isyarat Berbasis Pendidikan Karakter pada Siswa Kelas V di SDLB-B Negeri I Buleleng Tahun Pelajaran 2017/2018. Jurnal EDUTECH Undiksha, 8(2).

Rahmadi, F. (2015). Pengembangan Perangkat Pembelajaran Berbasis Pemecahan Masalah Berorientasi pada Kemampuan Penalaran dan Komunikasi Matematika. Pythagoras: Jurnal Pendidikan Matematika, 10(2), 137-145. https://doi.org/10.21831/pg.v10i2. 9133

Sari, W. R. (2016). Pengembangan perangkat pembelajaran bangun ruang di SMP dengan pendekatan pendidikan matematika realistik. Jurnal Riset Pendidikan Matematika, 3(1), 109-121.

Sugiyono, M. (2012). Metode Penelitian Kuantitatif, Kualitatif, dan Kombinasi. Bandung: Alfabeta.

Supriadi, N. (2015). Mengembangkan Kemampuan Koneksi Matematis Melalui Buku Ajar Elektronik Interaktif (BAEI) yang Terintegrasi Nilai-Nilai Keislaman. Al-Jabar: Jurnal Pendidikan Matematika, 6(1), 63-73.

Widyawati, S. (2016). Pengaruh Kemampuan Koneksi Matematis Siswa terhadap Prestasi Belajar Matematika Ditinjau dari Gaya Belajar pada Materi Bangun Ruang Sisi Datar Siswa Kelas IX SMP di Kota Metro. Iqra': Jurnal Kajian Ilmu Pendidikan, 1(1), 47-68.

Yuliasari, E. (2017). Eksperimentasi Model PBL dan Model GDL Terhadap Kemampuan Pemecahan Masalah
Matematis Ditinjau dari Kemandirian Belajar. Jurnal Ilmiah Pendidikan Matematika (JIPM), 6(1), 1-10. 